\title{
Water relations, photosynthesis, xylem embolism and accumulation of carbohydrates and cyclitols in two Eucalyptus species ( $E$. camaldulensis and $E$. torquata) subjected to dehydration-rehydration cycle
}

\author{
Samira Souden $^{1} \cdot$ Mustapha Ennajeh $^{1}$ (D) Sarra Ouledali ${ }^{1} \cdot$ Nooman Massoudi $^{2} \cdot$ Hervé Cochard $^{3} \cdot$ Habib Khemira $^{1,4}$
}

Received: 6 November 2019 / Accepted: 21 July 2020

○) Springer-Verlag GmbH Germany, part of Springer Nature 2020

Key message Resilience to xylem embolism and the accumulation of cyclitols are promising criteria for the selection of drought-resilient Eucalyptus species.

Abstract Due to the aridity of the climate in the southern Mediterranean region, the choice of suitable species for afforestation projects is crucial. The present study aims to compare resilience mechanisms against drought in two frequently used Eucalyptus species (E. camaldulensis and E. torquata). Two-year-old self-rooted cuttings of the two species were grown in sandfilled pots and subjected to a dehydration period followed by rehydration. At regular intervals, water relations, gas exchange, chlorophyll fluorescence and xylem embolism were measured on these plants. In addition, carbohydrates and cyclitols were quantified in their leaves. The results revealed that E. camaldulensis was more resilient to drought than E. torquata. During the dehydration phase, plant water status, cell turgor, net photosynthetic rate $\left(P_{\mathrm{n}}\right)$ and photosynthetic machinery integrity were less affected in E. camaldulensis than E. torquata. After rehydration, these variables were at levels similar to those of control plants in the case of E. camaldulensis, but not in the case of E. torquata. The restoration rate was $96 \%$ and $88 \%$ for predawn leaf water potential $\left(\Psi_{\mathrm{pd}}\right)$, and it was $98 \%$ and $77 \%$ for $P_{\mathrm{n}}$ in E. camaldulensis and E. torquata, respectively. The resilience of $E$. camaldulensis against drought may be due to the efficiency of two determinant survival mechanisms: osmotic adjustment and resistance to xylem embolism. Indeed, E. camaldulensis was less vulnerable to drought-induced xylem embolism and more able to repair embolized xylem vessels than E. torquata. Xylem refilling reduced embolism rate (percent loss of conductivity) to $15 \%$ in E. camaldulensis, compared to $22 \%$ in E. torquata. Furthermore, E. camaldulensis was found capable of efficient osmotic adjustment than E. torquata by accumulating soluble carbohydrates, especially cyclitols. Indeed, under severe drought $\left(\Psi_{\mathrm{pd}}\right.$ of $\left.-7 \mathrm{MPa}\right)$, E. camaldulensis accumulated $9.27 \mathrm{mg} \mathrm{g}^{-1} \mathrm{DW}$ of quercitol and $3.81 \mathrm{mg} \mathrm{g}^{-1} \mathrm{DW}$ of pinitol; it also had three times more myo-inositol in its leaves than E. torquata. We suggest the use of resilience to xylem embolism and the accumulation of cyclitols to screen Eucalyptus germplasm for drought resistance.

Keywords Chlorophyll fluorescence $\cdot$ Gas exchange $\cdot$ Osmotic adjustment $\cdot$ Quercitol $\cdot$ Resilience

\section{Introduction}

Mustapha Ennajeh

Mustapha.Ennajeh@fsg.rnu.tn

1 Laboratory of Biodiversity and Valorization of Bioresources in Arid Zones, Faculty of Sciences of Gabes, University of Gabes, 6072 Gabes, Tunisia

2 Commissariat Régional au Développement Agricole Gabès, CTV-Mareth, 6000 Gabes, Tunisia

3 Université Clermont-Auvergne, INRA, PIAF, 63000 Clermont-Ferrand, France

4 Center for Environmental Research and Studies (CERS), Jazan University, 82817 Jazan, Saudi Arabia
In the context of climate change, drought and rising temperatures are becoming a pervasive threat to plant survival, especially in arid regions (Correia et al. 2014; Villar et al. 2011). For instance, in the Mediterranean region, increased tree mortality has been attributed to extreme droughts (Bréda et al. 2006; Allen et al. 2010; Morales et al. 2013). The situation is aggravated by climate change; most models predict increased frequency and intensity of drought spells in the region (Edenhofer et al. 2014; Hoerling et al. 2012). Due to its geographic location, Tunisia is a transitional 
zone between the dry North African desert climate and the humid South European climate. In this Mediterranean country, rainfall is highly variable in space and time. Average annual rainfall ranges between $1500 \mathrm{~mm}$ in the northwest and less than $100 \mathrm{~mm}$ in the extreme arid southwest (Arnould and Hotyat 2003). This widely variable climate pattern affected the distribution of both spontaneous and cultivated plant species (El-Euch 2011; Toscano et al. 2019) with several indigenous and autochthonous species becoming endangered. Approximately $25 \%$ of Tunisia territory is affected by desertification (DGF 2007). In response, several initiatives were undertaken to protect and restore the most threatened regions (Zaafouri 1993; Albouchi et al. 2000). The annual rate of reforestation averaged 10,000 ha between 1962 and 1972, and then increased to approximately 13,500 ha between 1990 and 2008 (Bousnina et al. 2008; Chourabi 2014). Unfortunately, some of these projects failed for various reasons, but the principal cause was the lack of drought hardiness of used species which failed to adapt to the subsequent significant increase in aridity (Lamhamedi et al. 2000). Therefore, the success of future afforestation projects will depend largely on the careful choice of plant species capable of adapting to climatic disturbances. Thus, the use of drought-tolerant species, both native and exotic, is crucial. Several exotic plant species have been introduced in many arid and semi-arid areas of Tunisia. To evaluate the adaptation ability of these exotic species, thirty arboreta have been created in different climatic regions of the country (Poupon 1968). Among the species included in these trials, 177 Eucalyptus species have been planted in all arboreta (Khouja et al. 2001; Dia and Duponnois 2010).

Since 1950, Eucalyptus species were the most widely used exotic species for the rehabilitation of affected areas in Tunisia (Khouja 1999). Approximately 41,397 ha were planted with Eucalyptus species, approximately $6.1 \%$ of planted land in Tunisia (DGF 2007, 2010). This preference for Eucalyptus is principally related to its high drought tolerance (Navarrete-Campos et al. 2013). In addition to its ecological importance, in southern arid region of Tunisia where the present study was realized, Eucalyptus offers several economic benefices for the rural population. Eucalyptus trees are valuable for beekeeping in the region as their flowers constitute the main feeding source for bees particularly during years with low precipitation (Jilani et al. 2008). Eucalyptus leaves are also used for the extraction of essential oils which is the principle economic activity of many rural communities in the region. Eucalyptus wood is used in the production of charcoal for the local market and in shipbuilding.

The phenotypic plasticity of Eucalyptus species under drought conditions has been extensively studied (White et al. 2000; Merchant et al. 2007; Mokotedi 2010; Warren et al. 2011). In contrast, there are very few studies which looked into recuperation after drought episodes and the interlinked physiological and biochemical responses of the species to the stress. In arid and semi-arid zones of Tunisia, tree species used for rehabilitation of degraded ecosystems are characterized by drought resilience (drought resistance and recovery). Under such ecological conditions, it is important to use suitable species because ecosystem restoration is time consuming and costly. Therefore, it is crucial to choose reliable selection criteria of resilience against drought when screening tree germplasm.

Water stress commonly inflicts various perturbations on the primary as well secondary metabolisms of plants. First, it affects water relations and gas exchanges; then when it becomes more severe, the functional and structural integrities of many tissues and cell components might be compromised. Indeed, at leaf level, severe dehydration coupled with high light intensities causes over-excitation of photosynthetic pigment antennas leading to the production of reactive oxygen species (ROS) (Smirnoff 1993). ROS cause oxidative damages to the photosynthetic machinery and other vital cell macromolecules (Maxwell and Johnson 2000; Lawlor and Cornic 2002; Peltzer et al. 2002). In addition, severe drought increases tension of xylem sap leading to embolism when a specific threshold is reached (Tyree and Zimmermann 2002; Sevanto 2018). The dysfunction of xylem vessels results in the death of some parts or the whole tree (Cochard and Granier 1999; Brodersen and McElrone 2013). As an early response to water deficit, plants close their stomata; this reduces water loss by transpiration and prevents or at least delays xylem water potential from decreasing to levels which induce cavitation (Ennajeh et al. 2008). Thus, stomata play the role of safety valves for the xylem system. The second efficient defense mechanism against drought is osmotic adjustment, considered one of the most common responses of plants to water deficit (Morgan 1984). It is accomplished by the accumulation of various 'compatible solutes'. Carbohydrates are among the most and first accumulated solutes in leaves under drought (Ennajeh et al. 2006). In addition to being the source of energy and carbon for plant growth and development, many soluble sugars (sucrose, glucose and fructose) play also a key role in the response to water deficit (Chaves et al. 2003). First, they improve the water status of the plant by osmoregulation when water stress is moderate; then when the stress becomes severe, they participate in osmoprotection of the cells (Bohnert et al. 1995; Zhu 2001; Chaves et al. 2003). Additionally, several cyclitols (myo-inositol, quercitol, pinitol) are also considered 'compatible solutes' and possess other properties which contribute to drought tolerance Eucalyptus species (Merchant et al. 2006). Because of their hydroxyl groups, they may mimic the structure of water and maintain the structural integrity of membranes and macromolecules (Schobert 1977). They have antioxidant capacity by acting as scavengers of ROS thus preventing peroxydation of membrane lipids (Popp 
et al. 1997; Orthen and Popp 2000). They are involved also in signal transduction, membrane biogenesis and phosphate storage (Merchant et al. 2010). In several Eucalyptus species, mannitol, pinitol and quercitol accumulate in the leaves and roots under drought (Merchant et al. 2006; Warren et al. 2011). Despite the high interest in cyclitols in Eucalyptus, they have not been used in the selection of drought-resistant plant.

Eucalypts are well renowned for their tolerance of aridity, but they still exhibit significant inter- and intra-specific variability for this character (Merchant et al. 2006; Shvaleva et al. 2006; Merchant et al. 2010; Warren et al. 2011). Because Eucalyptus is often used for afforestation and reforestation projects in affected arid regions of Tunisia, it is essential to select the most drought-resilient species. This work came about in the general context of reevaluating and adjusting the list of plant species recommended for forestation projects which was established back in the 1950s.

The main objective of the present study was to compare the resistance to severe water deficit and the capacity to recover (restoration) after rehydration of two of the most widely used Eucalyptus species in Tunisia, i.e. E. camaldulensis and E. torquata. We explored the key defense mechanisms against drought which distinguish the two species. The underlying objective was to identify reliable selection criteria of resilience to drought in Eucalyptus species.

\section{Materials and methods}

\section{Plant material and treatments}

Two-year-old rooted cuttings (clones) of Eucalyptus camaldulensis and Eucalyptus torquata (Coral Gum), comparable in size (1 $\mathrm{m}$ in height), were used in this study. They were provided by the Nursery of Zerkine (Gabes, Tunisia). The plant material was obtained from mother trees in the nursery's collection. For each species, 21 trees were individually transplanted into 17 -L pots filled with a sandy soil (12\% coarse sand, $22 \%$ middle sand, $51 \%$ fine sand and $15 \%$ silt). The pots were covered with plastic film and aluminum foil to reduce evaporation from the soil surface and to minimize solar heating. The experiment was conducted outdoors on the campus of the Faculty of Science of Gabes (Gabes, Southern Tunisia: $33^{\circ} 50^{\prime} \mathrm{N}, 10^{\circ} 5^{\prime} \mathrm{E}$ ) during the period September to November 2015. The temperature ranged from 23 to $30{ }^{\circ} \mathrm{C}$ and air humidity ranged from 50 to $60 \%$.

After their transplantation in pots, the plants were watered to field capacity daily for 1 month. After this initial period of acclimatization, a drought treatment was imposed by suspending watering. This suspension was maintained until plants of both species exhibited a predawn leaf water potential $\left(\Psi_{\mathrm{pd}}\right)$ around $-7 \mathrm{MPa}$. This severe water stress level was reached after 45 days. Thereafter, three severely water-stressed plants from each species were rehydrated by daily watering for 30 days (rehydration phase).

Water relations, gas exchanges and leaf fluorescence variables were measured at regular 9-day intervals during the dehydration period (45 days) and at the end of the rehydration phase (after 30 days of watering) on three randomly selected plants per species. The measurements were carried out between 09:30 and 11:00 h. After measuring these ecophysiological parameters, stem samples were collected on the same plants to determine xylem embolism rate. A reasonable mass of leaves and roots were harvested separately, frozen in liquid nitrogen, and stored in a freezer $\left(-30{ }^{\circ} \mathrm{C}\right)$ for biochemical analyses.

\section{Plant water status}

Plant water status was evaluated by measuring $\Psi_{\mathrm{pd}}$ and minimum midday xylem water potential $\left(\Psi_{\text {xylem }}\right) . \Psi_{\text {pd }}$ was measured during early morning hours before sunrise on individual leaves, while $\Psi_{\text {xylem }}$ was determined by the coveredleaf technique. The leaves were enclosed in aluminum foil bags for at least $2 \mathrm{~h}$ before doing the measurements so to prevent leaf water loss and thus allow leaf and xylem water potentials to equilibrate. $\Psi_{\mathrm{pd}}$ and $\Psi_{\text {xylem }}$ were measured using a Scholander pressure chamber (PMS Instrument Company, Albany, OR, USA) (Scholander et al. 1965). In addition, the osmotic potential $\left(\Psi_{\mathrm{s}}\right)$ and turgor potential $\left(\Psi_{\mathrm{p}}\right)$ were determined on the same leaves used for $\Psi_{\mathrm{pd}}$ measurement. The $\Psi_{\mathrm{s}}$ was measured according to the method of Nobel (1991). To obtain cell contents, discs of $0.5 \mathrm{~cm}$ diameter obtained from fresh leaves were enclosed in a 0.5-ml Eppendorf tube perforated at its base. The tube was immerged in liquid nitrogen for a few seconds then removed and left to thaw for $5 \mathrm{~min}$; three freeze-thaw cycles were performed on each sample. The perforated Eppendorf was then placed in another larger ( $2 \mathrm{ml}$ ) non-perforated tube which was centrifuged at $8000 \times g$ for $5 \mathrm{~min}$ at a temperature of $4{ }^{\circ} \mathrm{C}$. The exudates from the discs were collected in the larger tube. $\Psi_{\mathrm{s}}$ of the exudates was measured using an osmometer (WESCOR, VAPRO model 5600, UT, USA).

The $\Psi_{\mathrm{p}}$ was calculated as the difference between predawn water potential and osmotic potential:

$\Psi \mathrm{p}=\Psi \mathrm{pd}-\Psi \mathrm{s}$

\section{Gas exchanges}

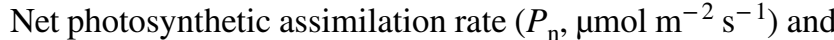
stomatal conductance $\left(g_{\mathrm{s}}, \mathrm{mol} \mathrm{m}^{-2} \mathrm{~s}^{-1}\right)$ were measured on mature leaves using CI-340 portable photosynthesis system (ADC BioScientific Ltd, Hoddesdon, UK). Measurements 
were taken at ambient conditions between 0930 and $1030 \mathrm{~h}$ under fully saturating light conditions with temperatures between 20 and $30{ }^{\circ} \mathrm{C}$. The measurements were repeated three times for each of three leaves per plant. A total of three plants per treatment were used each time.

\section{Chlorophyll fluorescence}

Chlorophyll fluorescence was measured right after gas exchange measurements between 1030 and $1100 \mathrm{~h}$ with a portable fluorometer OS1-FL (Opti-Sciences, Hudson, NH, USA). The measurements were performed on dark-acclimated leaves. These leaves were adapted to darkness for at least 20 min (Genty et al. 1989) using light exclusion clips (FL-DC, Opti-Sciences, Hudson, NH, USA). We measured minimum $\left(F_{0}\right)$ and maximum $\left(F_{\mathrm{m}}\right)$ chlorophyll fluorescence of dark-adapted leaves. These chlorophyll fluorescence yields were used to calculate maximum quantum efficiency of photosystem II (PSII):

$F_{v} / F_{m}=\frac{\left(F_{m}-F_{0}\right)}{F_{m}}$

(Maxwell and Johnson 2000).

\section{Xylem embolism}

The relative changes in xylem conductivity between native and water-saturated states were used as proxies for vulnerability to drought-induced xylem embolism inferred from the percent loss of conductivity (PLC) after removal of xylem embolism by repeated high-pressure flushes. To measure xylem hydraulic conductivity, the stem of each plant was excised under water to prevent air embolism induction at the time of sample collection. Samples were immediately placed in black plastic bags with humidified papers to prevent water loss by transpiration before xylem hydraulic conductivity $(K)$ measurements. During each interval of the experiment, $K$ was measured in stem samples according to the method described by Sperry et al. (1988). The technique involves measuring the hydraulic conductivity of $3-\mathrm{cm}$-long stem segments before ( $K$ initial, $K \mathrm{i})$ and after ( $K$ maximum, $K \mathrm{~m})$ water refilling. Stem segments were excised under water to prevent any practice-induced cavitation. Their cut-ends were re-cut with a sharp razor blade. One of the cut ends was then attached to the hydraulic apparatus. Flow rates were measured with an analytical balance $( \pm 0.1 \mathrm{mg})$ interfaced to a computer. The measurement solution was $20 \mathrm{mM} \mathrm{KCL}$ and $1 \mathrm{mM} \mathrm{CaCl}_{2}$ in ultrapure water. The measurement delivery pressure was about $6 \mathrm{KPa}$. The solution flowed from a beaker sitting on the balance trough the stem segment, which was kept under water during the measurements. We measured $\mathrm{Ki}$ at low pressure $(6 \mathrm{kPa})$ so that no-technical artifacts may arise because this pressure is not enough to blow air bubbles out of open vessels in 3-cm-long stem segments. Therefore, $K i$ would not be over-estimated and PLC would not be under-estimated. To measure $K \mathrm{~m}$, air obstructing stem xylem vessels was removed by applying a series of 10 -s hydraulic pressure flushes (0.2 MPa) until measured values of $K \mathrm{~m}$ remained constant between flushes. $K \mathrm{i}$ and $\mathrm{Km}$ were used to calculate the percent loss of hydraulic conductivity (PLC) as

$\operatorname{PLC}(\%)=\frac{(K \mathrm{~m}-K \mathrm{i})}{K \mathrm{~m}} \times 100$

Xylem embolism in the stem was quantified by the PLC. Embolism vulnerability curves (VCs) were constructed by plotting the PLC values against $\Psi_{\text {xylem }}$ (SigmaPlot10; Sigmoidal, Sigmoid, 3 Parameter). The value of PLC, due to the air blockage, is an indirect estimate of the percentage of embolized vessels (Cochard et al. 2000).

\section{Contents of carbohydrates and cyclitols}

Because of their key role in plant response to drought, total soluble sugars, glucose, fructose, myo-inositol, quercitol and pinitol were quantified in the leaves of both studied Eucalyptus species. Total soluble sugars content was determined using the phenol-sulfuric acid method (Robyt and White 1987). For their extraction, $0.2 \mathrm{~g}$ samples of liquid nitrogen frozen and powdered leaves were mixed with $5 \mathrm{ml}$ of $80 \%$ methanol. The homogenate was heated in a water bath at $70{ }^{\circ} \mathrm{C}$ for $30 \mathrm{~min} .1 \mathrm{ml}$ of the extract was added to $1 \mathrm{ml}$ of $5 \%$ phenol (v/v) and $5 \mathrm{ml}$ of concentrated sulfuric acid. After agitation and cooling, the absorbance (Do) was measured at a $640 \mathrm{~nm}$ wavelength. The concentration of total soluble sugars was determined by reference to a standard curve prepared using glucose solutions ranging in concentration from 0.05 to $0.3 \mathrm{mg} \mathrm{ml}^{-1}$.

Glucose, fructose, myo-inositol, quercitol and pinitol were quantified according to the method of Moing et al. (1992). They were extracted from $30 \mathrm{mg}$ powdered dry leaves mixed with $80 \%$ ethanol and heated to $80{ }^{\circ} \mathrm{C}$ for $30 \mathrm{~min}$ in a thermostatic bath. Then the mixture was centrifuged at $1000 \times \mathrm{g}$ for $10 \mathrm{~min}$. The supernatant was recuperated. The pellet of the same sample was subjected to a second extraction with $80 \%$ ethanol and a third one with $50 \%$ ethanol. The three supernatants containing carbohydrates and cyclitols were filtered through $0.22-\mu \mathrm{m}$-porosity filter. The filtrate was dried with a Speed Vacuum Concentrator (Speed-Vac Plus SC110A, Thermo Savant, Holbrook, NY, USA). The resulted residue was solubilised in $1 \mathrm{ml}$ of ultra-pure water in an ultrasonic bath (Bioblock Scientific, Germany) for $15 \mathrm{~min}$. Aliquots of the extract were analyzed with a High Performance Liquid Chromatograph (HPLC, 
817 BIOSCAN, METROHM, Herisau, Switzerland) using a Metrosep Carb 2 250/4.0 (Herisau, Switzerland) column. The mobile phase, $\mathrm{NaOH} 0.2 \mathrm{~N}$, was pumped at a flow rate of $0.6 \mathrm{ml} \mathrm{min}{ }^{-1}$. The temperature was adjusted to $37{ }^{\circ} \mathrm{C}$. Quantification of carbohydrates and cyclitols was made by comparison with external respective standards.

\section{Statistical analysis}

The experiment was arranged as a Completely Randomized Design with three replicates. All values of variables are the means of at least three replicates $\pm \mathrm{SE}$. The data were subjected to a statistical analysis of variance (ANOVA) using GLM procedure of SAS software (SAS Institute 1999) with a level of significance $P<0.05$.

\section{Results}

\section{Plant water relations}

The $\Psi_{\mathrm{pd}}$ of well-watered plants was high at $-1 \mathrm{MPa}$ and $-0.7 \mathrm{MPa}$ for E. torquata and E. camaldulensis, respectively (Fig. 1). Withholding irrigation affected plant water status for both species. The decline of $\Psi_{\mathrm{pd}}$ was similar for the two species when water deficit was moderate. However, when the deficit became severe after 28 days of drought treatment, $\Psi_{\text {pd }}$ of E. camaldulensis became more negative ( $-5.5 \mathrm{MPa}$ ) than that of E. torquata ( $-4.9 \mathrm{MPa})$. This difference between the two species increased after 45 days of no-irrigation; $\Psi_{\mathrm{pd}}$ was $-7.8 \mathrm{MPa}$ and $-7.1 \mathrm{MPa}$ in E. camaldulensis and $E$. torquata, respectively. Restoring irrigation (rehydration)

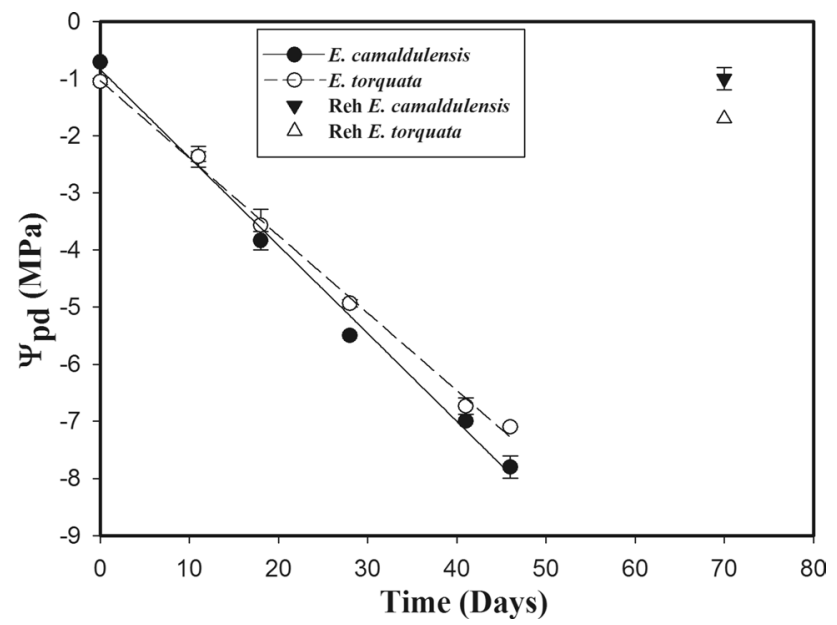

Fig. 1 Variation of predawn leaf water potential $\left(\Psi_{\mathrm{pd}}\right)$ as a function of time (days) in two Eucalyptus species (E. camaldulensis and E. torquata) subjected to dehydration period followed by rehydration (Reh). Each point is the average of three replicates and the vertical bars indicate SE allowed the plants of both species to regain their pre-stress $\Psi_{\text {pd }}$ levels. However, the restoration rate was better in $E$. camaldulensis than E. torquata ( $96 \%$ vs. $88 \%$ ).

Plotting $\Psi_{\mathrm{s}}$ as a function of $\Psi_{\mathrm{pd}}$ shows that, when water was available, both Eucalyptus species had similarly high $\Psi_{\text {s }}$ of about $-1.8 \mathrm{MPa}$ (Fig. 2a). However, when water became deficient, $\Psi_{\mathrm{s}}$ decreased significantly $(P=0.0001)$. This reduction was rapid and more acute in E. camaldulensis than in $E$. torquata $(P=0.03)$. After resuming watering, $\Psi_{\mathrm{s}}$ of both Eucalyptus species regained its pre-stress values.

Water deficit caused $\Psi_{\mathrm{p}}$ to decrease in both Eucalyptus species (Fig. 2b) albeit more so E. torquata $(P=0.005)$. Indeed, under water stress conditions, the decrease of $\Psi_{\mathrm{p}}$ was rapid and acute in E. torquata, but slight and progressive in E. camaldulensis. Cell turgor loss occurred at $\Psi_{\mathrm{pd}}$ of $-2 \mathrm{MPa}$ in E. torquata but only starting from $-4 \mathrm{MPa}$ in E. camaldulensis. After 1 month of rehydration, cell turgor was restored in both species but more so in E. camaldulensis $(0.8 \mathrm{MPa})$ than in E. torquata $(0.4 \mathrm{MPa})$.

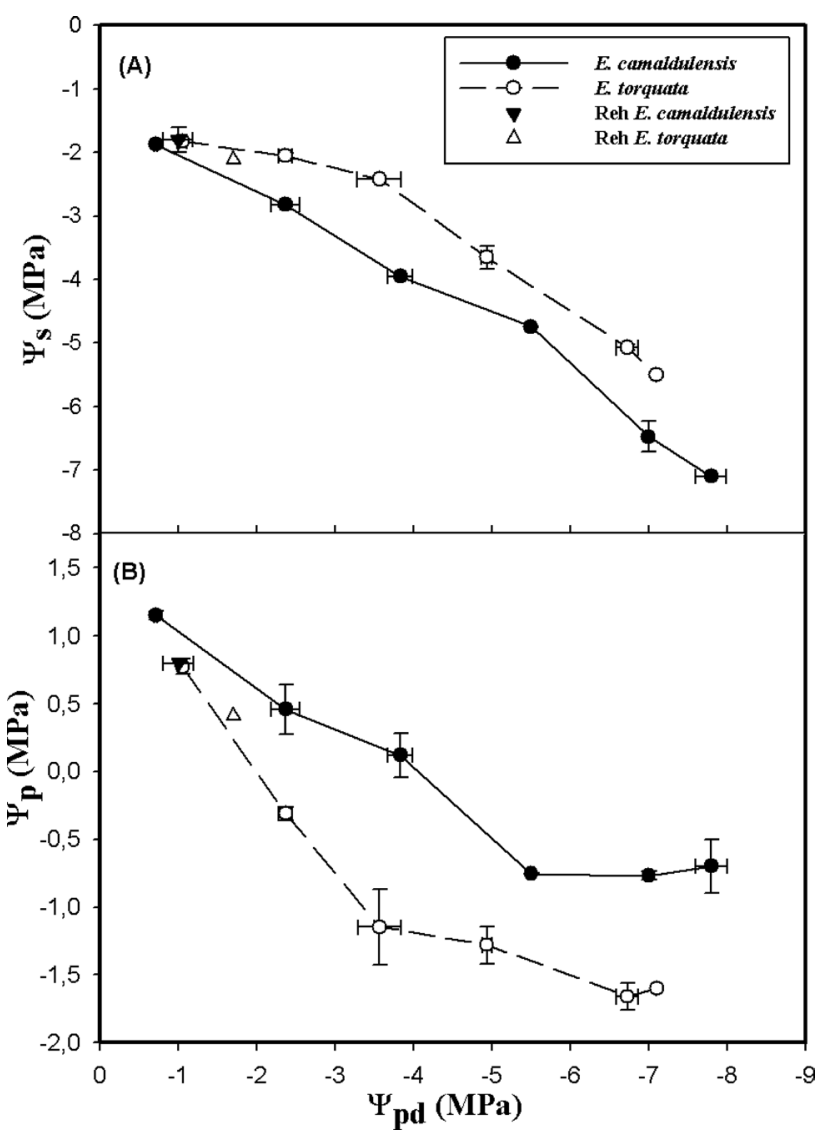

Fig. 2 Variation of a osmotic potential $\left(\Psi_{\mathrm{s}}\right)$ and $\mathbf{b}$ turgor potential $\left(\Psi_{\mathrm{p}}\right)$ as a function of predawn leaf water potential $\left(\Psi_{\mathrm{pd}}\right)$ in two Eucalyptus species (E. camaldulensis and E. torquata) subjected to dehydration period followed by rehydration (Reh). Each point is the average of three replicates and the vertical bars indicate SE 


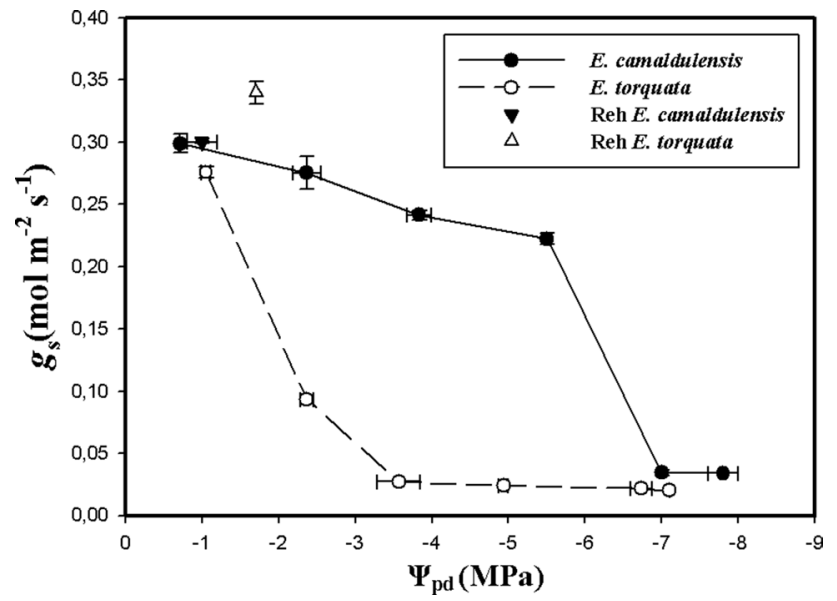

Fig. 3 Variation of stomatal conductance $\left(g_{s}, \mathrm{~mol} \mathrm{~m}^{-2} \mathrm{~s}^{-1}\right)$ as a function of predawn leaf water potential $\left(\Psi_{\mathrm{pd}}\right)$ in two Eucalyptus species (E. camaldulensis and E. torquata) subjected to dehydration period followed by rehydration (Reh). Each point is the average of 27 measurements and the vertical bars indicate SE

\section{Stomatal behavior}

Changes in leaf $g_{\mathrm{s}}$ according to plant water status showed a contrasted behavior between the two studied Eucalyptus (Fig. 3). Water deficit caused $g_{\mathrm{s}}$ to drop in E. torquata plants even earlier (at lower stress intensity); whereas E. camaldulensis maintained relatively high $g_{\mathrm{s}}\left(0.222 \mathrm{~mol} \mathrm{~m}^{-2} \mathrm{~s}^{-1}\right)$ until $\Psi_{\mathrm{pd}}$ of about $-5.5 \mathrm{MPa}$. The tight closure of stomata was observed starting from $-3.5 \mathrm{MPa}$ in $E$. torquata but only at $-7 \mathrm{MPa}$ in E. camaldulensis. After rehydration phase, both species regained their pre-stress $g_{\mathrm{s}}$ levels.

\section{Photosynthesis and chlorophyll fluorescence}

The two species differed in their photosynthetic response to water availability (Fig. 4). When leaf tissues were well hydrated $\left(\Psi_{\mathrm{pd}} \approx-1 \mathrm{MPa}\right)$, plants of both species had high photosynthetic assimilation rates although E. camaldulensis exhibited higher $P_{\mathrm{n}}$ values than E. torquata $(15.2 \mu \mathrm{mol}$ $\mathrm{m}^{-2} \mathrm{~s}^{-1}$ vs. $11.4 \mu \mathrm{mol} \mathrm{m}{ }^{-2} \mathrm{~s}^{-1}$, respectively). Under the water deficit regime, $P_{\mathrm{n}}$ decreased significantly in both plant species. However, it is worth noticing that for the same leaf water status $\left(\Psi_{\mathrm{pd}}\right), P_{\mathrm{n}}$ of $E$. camaldulensis was higher than that of E. torquata throughout the whole range of $\Psi_{\mathrm{pd}}$. For instance, when water deficit became severe $\left(\Psi_{\mathrm{pd}}<-5 \mathrm{MPa}\right)$, $P_{\mathrm{n}}$ of E. torquata was less than $2 \mu \mathrm{mol} \mathrm{m} \mathrm{m}^{-2} \mathrm{~s}^{-1}$, whereas $P_{\mathrm{n}}$ of $E$. camaldulensis was more than $6 \mu \mathrm{mol} \mathrm{m}^{-2} \mathrm{~s}^{-1}$. After 30 days of rehydration, E. camaldulensis regained its pre-stress $P_{\mathrm{n}}$ values. While $P_{\mathrm{n}}$ of $E$. torquata plants was about $77 \%$ of its pre-stress level.

When water deficit was low or moderate $\left(\Psi_{\mathrm{pd}}\right.$ between -1 and $-3.5 \mathrm{MPa}$ ), the $F_{0}$ values of dark-adapted leaves

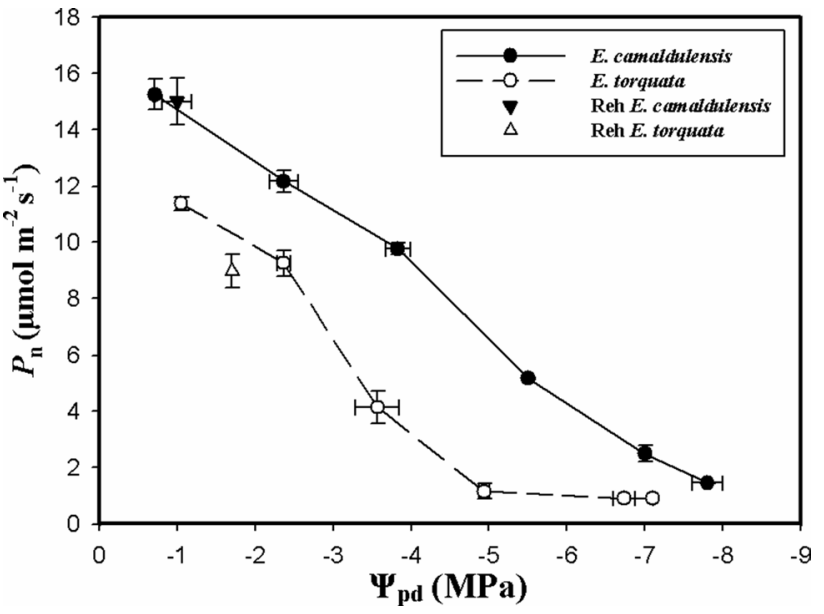

Fig. 4 Variation of net photosynthetic rate $\left(P_{\mathrm{n}}, \mu \mathrm{mol} \mathrm{m} \mathrm{m}^{-2} \mathrm{~s}^{-1}\right)$ as a function of predawn leaf water potential $\left(\Psi_{\mathrm{pd}}\right)$ in two Eucalyptus species (E. camaldulensis and E. torquata) subjected to dehydration period followed by rehydration (Reh). Each point is the average of 27 measurements and the vertical bars indicate SE

of the two Eucalyptus species were not significantly different $(P=0.323)$; they were stable and low compared to values of recorded for severely water-stressed plants (Fig. 5a). However, when drought stress intensified, the two species behaved differently. Indeed, $F_{0}$ of $E$. torquata leaves increased $(P=0.013)$ relative to levels recorded when $\Psi_{\mathrm{pd}}$ was more than $-3.5 \mathrm{MPa}$; but it remained unchanged for lower $\Psi_{\mathrm{pd}}$ levels in E. camaldulensis. Significant difference in $F_{0}$ between the two species appeared for $\Psi_{\text {pd }}$ less than $-5.5 \mathrm{MPa}$; E. camaldulensis showed lower $F_{0}$ values than E. torquata.

In well-watered plants, $F_{\mathrm{m}}$ was high, but it was more so in E. camaldulensis than in E. torquata (Fig. 5b). Water deficit appeared to reduce $F_{\mathrm{m}}$ especially in the latter species. In fact, for the same $\Psi_{\mathrm{pd}}$ value, E. torquata showed lower $F_{\mathrm{m}}$ values than E. camaldulensis.

The ratio $F_{\mathrm{V}} / F_{\mathrm{m}}$ was modulated by both plant water status and genotype (Fig. 5c). When leaves were well hydrated, $F_{\mathrm{V}} / F_{\mathrm{m}}$ was high in both Eucalyptus species, but it was higher in E. camaldulensis than in E. torquata. $F_{\mathrm{V}} / F_{\mathrm{m}}$ decreased as water stress intensified. However, $E$. camaldulensis maintained a higher $F_{\mathrm{V}} / F_{\mathrm{m}}(0.71)$ compared to E. torquata ( 0.63 ) for the same leaf tissue hydration until a $\Psi_{\text {pd }}$ of $-4 \mathrm{MPa}$. Under severe drought conditions, both Eucalyptus species exhibited similarly low $F_{\mathrm{V}} / F_{\mathrm{m}}$ values.

After 30 days of re-watering, both species regained pre-stress levels of all measured fluorescence variables (Fig. 5). This could indicate the restoration of structural and functional integrity of their photosynthetic machineries. 


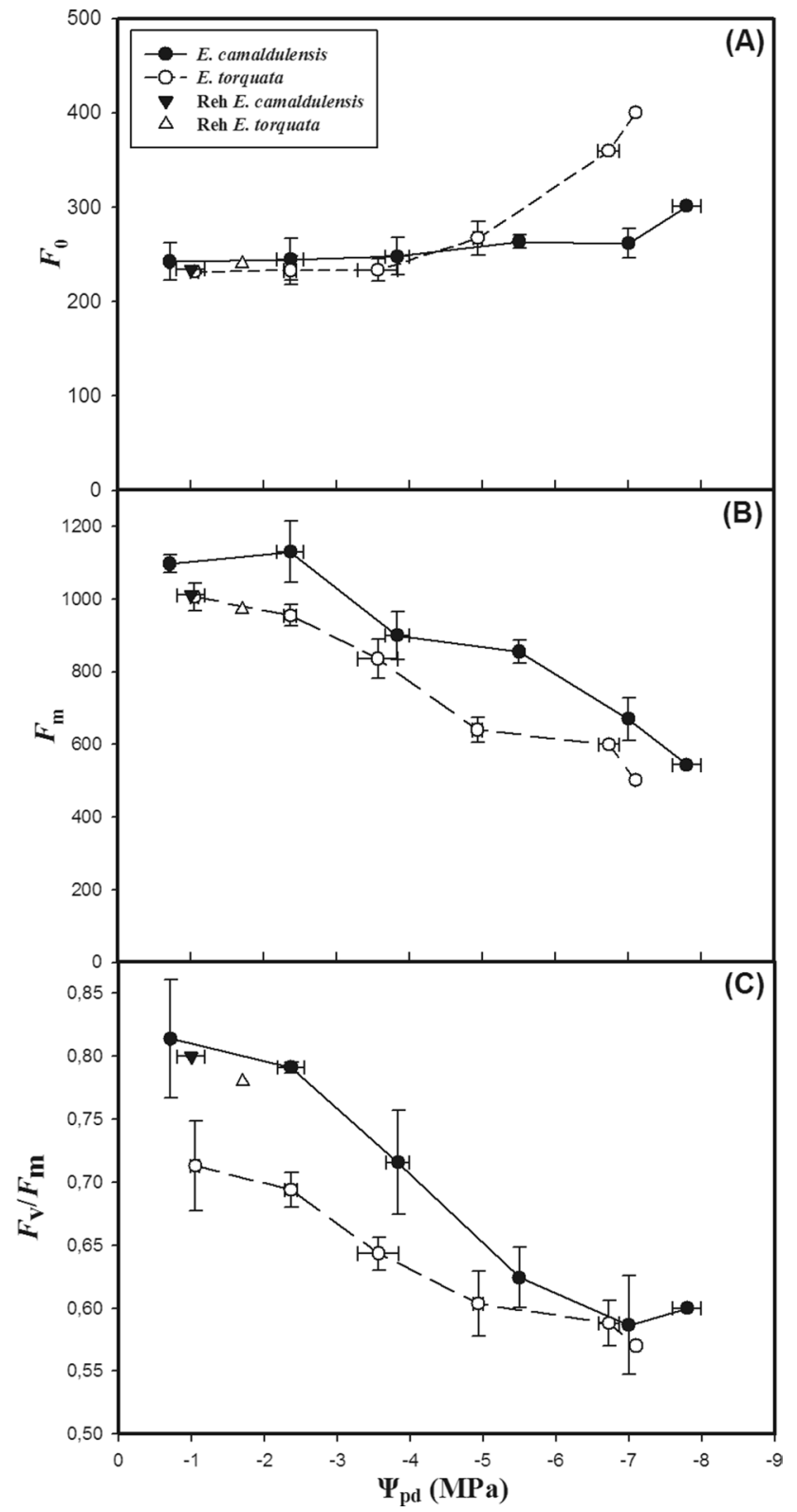

Fig. 5 Variation of a minimum chlorophyll fluorescence $\left(F_{0}\right)$, b maximum chlorophyll fluorescence $\left(F_{\mathrm{m}}\right)$ and $\mathbf{c}$ maximum quantum efficiency of PSII $\left(F_{\mathrm{V}} / F_{\mathrm{m}}\right)$ as a function of predawn leaf water potential $\left(\Psi_{\mathrm{pd}}\right)$ in two Eucalyptus species (E. camaldulensis and E. torquata) subjected to dehydration period followed by rehydration (Reh). Each point is the average of nine measurements and the vertical bars indicate SE

\section{Xylem embolism}

Curves of vulnerability to xylem embolism show interspecific differences between the two genotypes (Fig. 6). E. camaldulensis was less vulnerable to xylem cavitation than E. torquata. The value of $\Psi_{\text {xylem }}$ which induced $50 \%$ PLC $\left(\Psi_{50}\right)$ was $-5.5 \mathrm{MPa}$ in E. camaldulensis and $-4.6 \mathrm{MPa}$ in E. torquata. After 30 days of rehydration, the level of

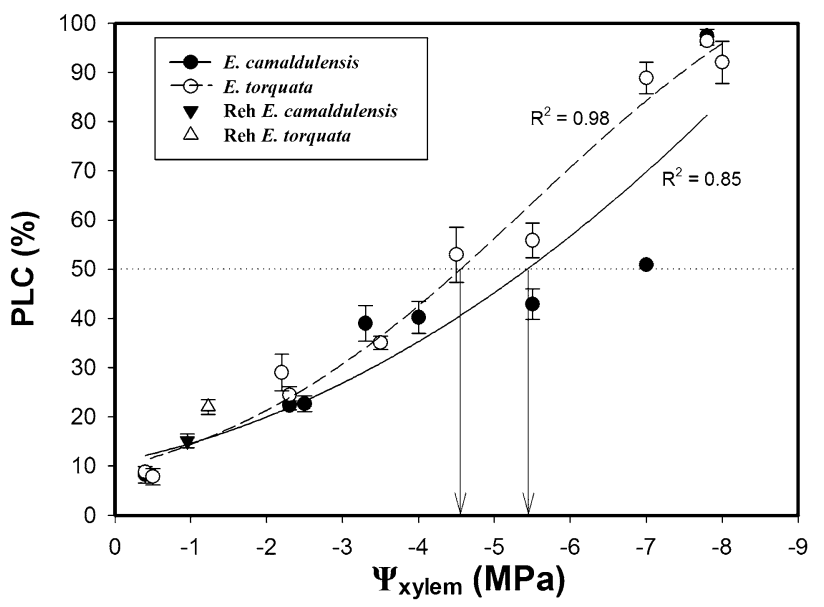

Fig. 6 Vulnerability curves to drought-induced xylem embolism and percent loss of xylem conductivity (PLC) after rehydration (Reh) in two Eucalyptus species (E. camaldulensis and E. torquata). Rows indicate minimum midday xylem water potential $\left(\Psi_{50}\right)$ inducing $50 \%$ of PLC. Each point is the average of at least three replicates and the vertical bars indicate $\mathrm{SE}$

xylem embolism decreased in both species, but more acutely in E. camaldulensis (PLC $=15 \%$ ) than in E. torquata $(\mathrm{PLC}=22 \%)$. This indicates the higher ability of E. camaldulensis to restore its xylem conductivity.

\section{Changes in the concentrations of carbohydrates and cyclitols}

The accumulation of total soluble sugars in the leaves of well-watered and moderately dehydrated plants showed similar trends for both species (Fig. 7a). Indeed, at field capacity, leaf soluble sugar content was low $\left(28 \mathrm{mg} \mathrm{g}^{-1} \mathrm{FW}\right)$. As drought stress intensified, these osmotica accumulated strongly in both species until $\Psi_{\mathrm{pd}}$ of $-5 \mathrm{MPa}$. At more negative $\Psi_{\mathrm{pd}}$ values, the accumulation of soluble sugars differed between the two species. In E. camaldulensis, total soluble sugars content continued to increase until reaching $270 \mathrm{mg}$ $\mathrm{g}^{-1} \mathrm{FW}$ at the lowest measured $\Psi_{\mathrm{pd}}$ of $-7.8 \mathrm{MPa}$, whereas in E. torquata, total soluble sugar content peaked at $\Psi_{\mathrm{pd}}$ of - 4.9 MPa then decline rapidly at lower $\Psi_{\mathrm{pd}}$ until reaching $130 \mathrm{mg} \mathrm{g}^{-1} \mathrm{FW}$ at $\Psi_{\mathrm{pd}}$ of $-7.1 \mathrm{MPa}$. After rehydration, leaf total soluble sugar content regained pre-stress level in E. camaldulensis, but it was higher in rehydrated plants of E. torquata than in unstressed ones.

As for glucose and fructose, their accumulation depended on water treatment and genotype (Fig. 7b, c). E. torquata consistently accumulated less glucose and fructose than $E$. camaldulensis. Unstressed and moderately stressed plants of $E$. torquata were low in glucose and fructose; as water deficit intensified, these sugars accumulated progressively to reach $18.7 \mathrm{mg} \mathrm{g}^{-1} \mathrm{FW}$ and $24 \mathrm{mg} \mathrm{g}^{-1} \mathrm{FW}$, respectively, 


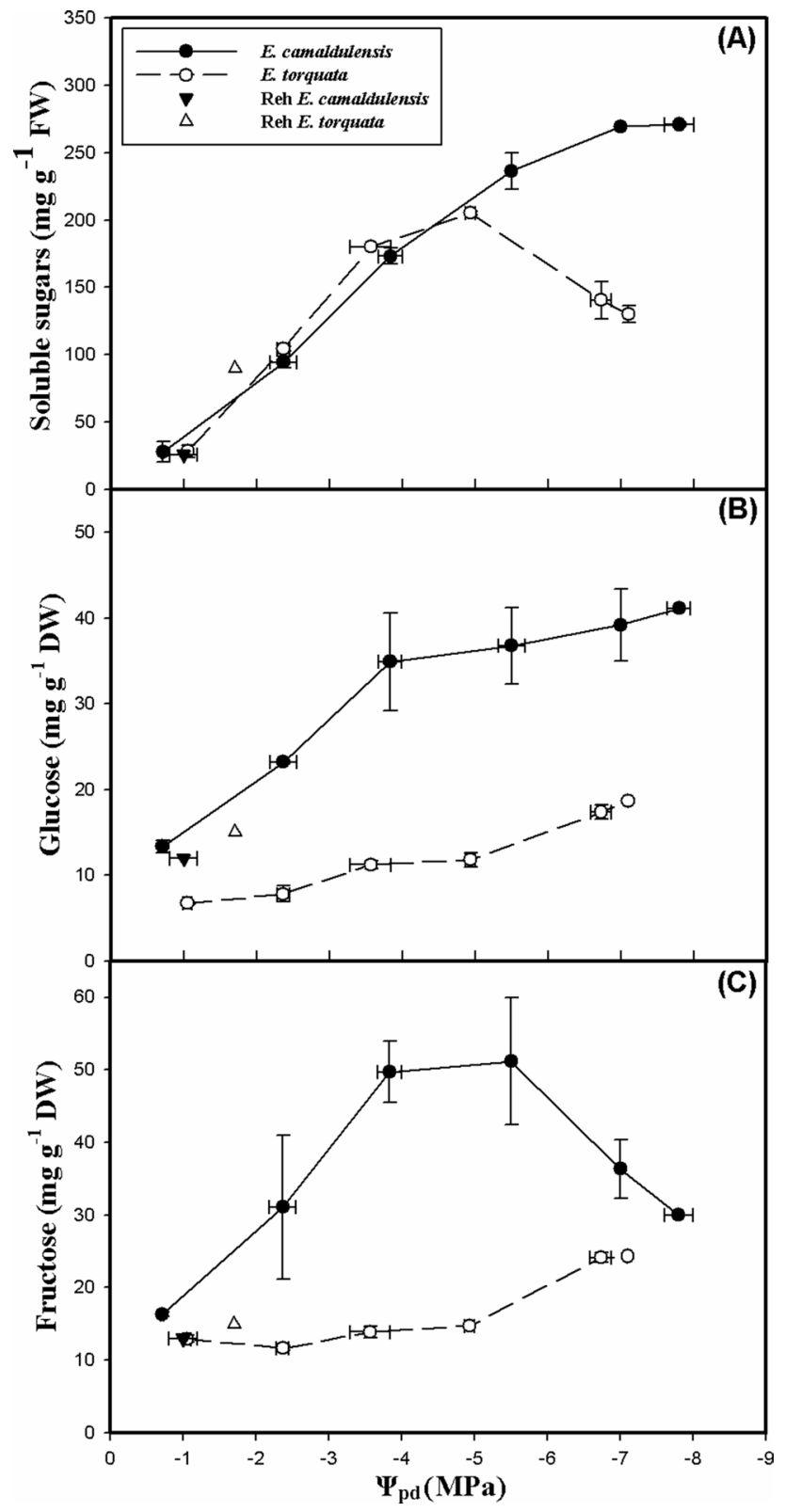

Fig. 7 Variation of a total soluble sugars content, $\mathbf{b}$ glucose content and $\mathbf{c}$ fructose content as a function of predawn leaf water potential $\left(\Psi_{\text {pd }}\right)$ in leaves of two Eucalyptus species (E. camaldulensis and E. torquata) subjected to dehydration period followed by rehydration (Reh). Each point is the average of three replicates and the vertical bars indicate SE

whereas in E. camaldulensis, glucose and fructose accumulated differently according to water stress intensity. Indeed, glucose content was strongly enhanced as $\Psi_{\text {pd }}$ decreased. At the end of the drought treatment, it was four times its initial level. Whereas fructose concentration peaked at $51.19 \mathrm{mg}$ $\mathrm{g}^{-1} \mathrm{FW}$ when $\Psi_{\mathrm{pd}}$ was $-5.5 \mathrm{MPa}$, below this water potential, fructose content declined sharply. Rehydrated plants of $E$. camaldulensis accumulated fructose and glucose similar to

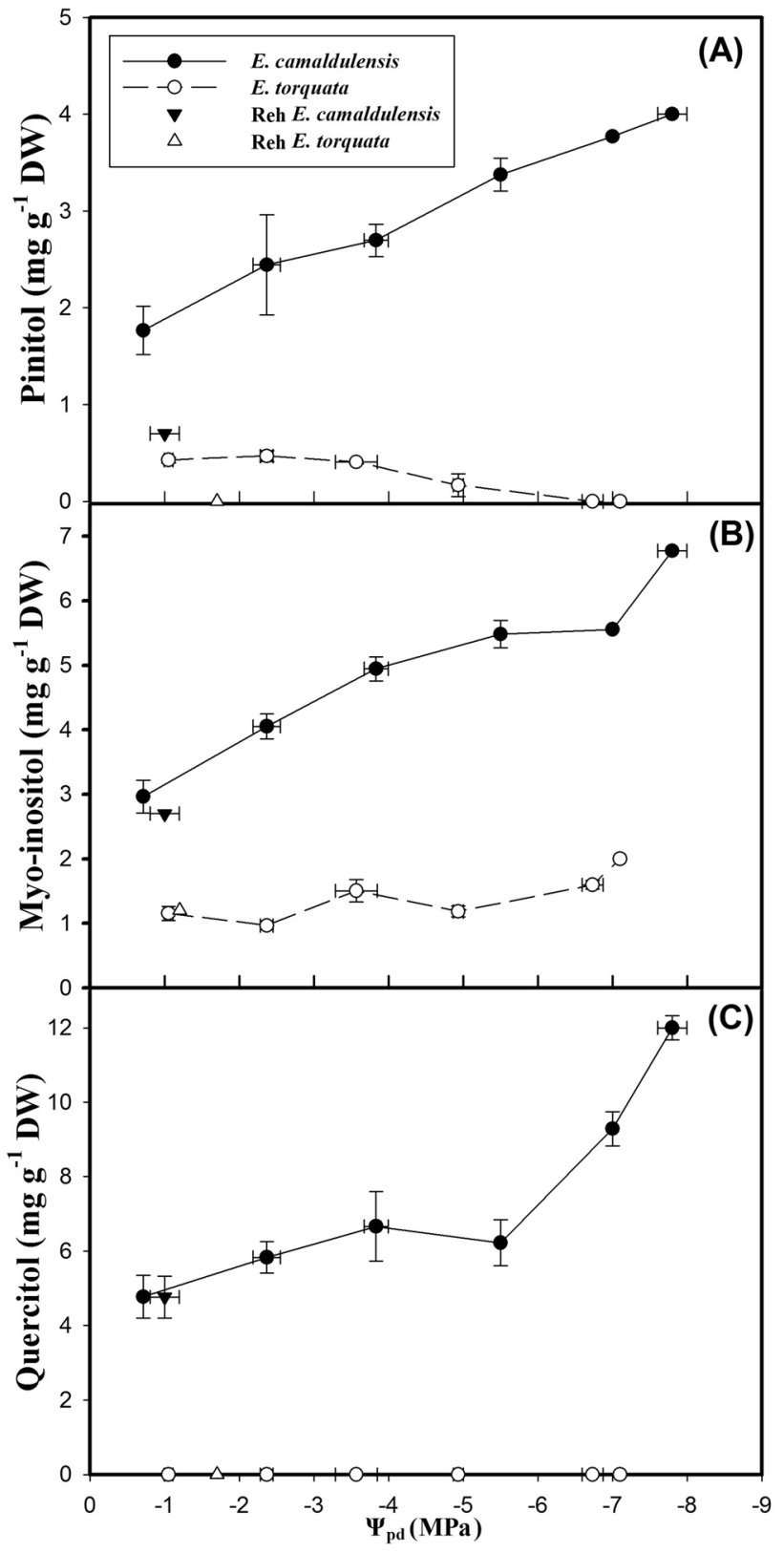

Fig. 8 Variation of contents of three cyclitols: a pinitol, b myo-inositol and $\mathbf{c}$ quercitol as a function of predawn leaf water potential $\left(\Psi_{\mathrm{pd}}\right)$ in leaves of two Eucalyptus species (E. camaldulensis and E. torquata) subjected to dehydration period followed by rehydration (Reh). Each point is the average of three replicates and the vertical bars indicate SE

well-watered plants. However, in E. torquata, the concentrations of the two sugars were higher after rehydration than during the acclimation phase. For instance, glucose content of rehydrated plants was two times that of control unstressed plants.

Figure 8 represents the accumulation over time of three cyclitols (pinitol, myo-inositol and quercitol) in the leaves of the two Eucalyptus species. The concentration differed 
among compounds, species and stress intensity. E. camaldulensis plants accumulated more cyclitols in their leaves than $E$. torquata. Indeed, in unstressed plants, pinitol content in E. camaldulensis was four times more than in $E$. torquata (Fig. 8a). Under drought conditions, it accumulated progressively in the first species as stress intensified, whereas it remained low in the second one. Leaves of rehydrated plants of both species contained low quantities of pinitol. The myo-inositol concentration showed a similar trend to pinitol. It was greater in E. camaldulensis compared to E. torquata throughout the whole range of $\Psi_{\text {pd }}$ values (Fig. 8b). In addition, it accumulated in E. camaldulensis leaves as water deficit intensified but remained unchanged in the leaves of E. torquata. Finally, there was significant inter-specific difference in quercitol concentration (Fig. 8c). Indeed, E. torquata plants did not accumulate this cyclitol in their leaves, whereas E. camaldulensis plants accumulated large quantities of quercitol especially under severe drought (from $\Psi_{\mathrm{pd}}$ lower than $-5.5 \mathrm{MPa}$ ). The concentration was $12 \mathrm{mg} \mathrm{g}^{-1} \mathrm{DW}$ at $\Psi_{\mathrm{pd}}$ of $-7.8 \mathrm{MPa}$ in the severely water-stressed plants. After rehydration, this concentration decreased to levels found in well-hydrated unstressed plants.

\section{Discussion}

Water scarcity is one of the most limiting factors to Eucalyptus growth in xeric environments (Bachelard 1985; Stape et al. 2004). The ability of Eucalyptus species to cope with water stress depends on their genotype (Warren et al. 2011; 2012). Biochemical and physiological mechanisms involved in tree survival during severe dehydration and those implicated in recovery during rehydration are crucial for resilience to acute drought. The results of our study revealed inter-species differences in the response to severe water deficit in Eucalyptus. It appears that E. camaldulensis was more resilient to drought than E. torquata; its water status, cell turgor, photosynthetic activity and cell membrane integrity were less affected by desiccation than those of E. torquata. After rehydration, all these variables were totally restored to pre-stress levels in E. camaldulensis, but only partially in E. torquata. Furthermore, the former species accomplished efficient osmotic adjustment and good resilience to xylem embolism. It accumulated large quantities of soluble carbohydrates and especially cyclitols and exhibited less vulnerability to drought-induced xylem embolism and higher ability of xylem refilling than E. torquata. Osmotic adjustment is critical for both plant growth and survival (Blum, 2017) whereas resistance to xylem embolism is key to survival in environments afflicted by drought and salinity (Hacke and Sperry 2003).

\section{Plant hydration and integrity of photosynthetic machinery}

Susceptibility to drought depends on both stress intensity and the plant's genetic makeup (Demirevska et al. 2009). Our results show different responses to water deficit between the two Eucalyptus species (E. camaldulensis, E. torquata). These differences were apparent during the time of exposure to water deficit as well as during the restoration phase after resuming irrigation. To be sure water deficit severely afflicted the water status of plants of both Eucalyptus species. This is an expected effect of drought on most woody species such as olive tree (Tognetti et al. 1999; Merchant et al. 2006; Ennajeh et al. 2008), Eucalyptus globulus (Guarnaschelli et al. 2003) and Acacia tortilis (El-Atta et al. 2012). However, in our study, a significant difference appeared between the two studied Eucalyptuses as $\Psi_{\text {pd }}$ decreased more in E. camaldulensis than in E. torquata. This strong reduction of $\Psi_{\mathrm{pd}}$ in E. camaldulensis suggests that it is more resistance to drought rather than sensitive since it maintained higher cell turgor. In fact, the sharper decline of $\Psi_{\mathrm{pd}}$ of E. camaldulensis was not due to a decrease of $\Psi_{\mathrm{p}}$, instead it was caused by a stronger decline of $\Psi_{\text {s }}$ compared to the values measured in $E$. torquata. Indeed, the former species was more efficient at osmoregulation by accumulating various osmotica. Several studies demonstrated that osmotic adjustment is a common response to water deficit within the genus Eucalyptus (Lemcoff et al. 2002; Guarnaschelli et al. 2003; Aranda et al. 2005; Merchant et al. 2006; Merchant et al. 2007). Similar to what we found in the present study, E. dumosa and E. pauciflora, were reported to respond to severe water stress by accumulating osmotically active solutes in their leaves and keeping their $\Psi_{\mathrm{s}}$ low (Warren et al. 2012).

Perturbations in plant-water relations commonly have direct repercussions on other vital physiological processes in the plant like gas exchanges especially photosynthetic activity (Chaves 1991; Sapeta et al. 2013). Hu et al. (2012) noticed that $P_{\mathrm{n}}$ in $E$. grandis leaves decreased after 6 days without watering. In the present study, water deficit caused $P_{\mathrm{n}}$ to decrease in both species, but $E$. camaldulensis maintained a higher $P_{\mathrm{n}}$ than $E$. torquata throughout the full range of $\Psi_{\mathrm{pd}}$. In E. camaldulensis, the delayed closure of stomata appears to have helped maintain $P_{\mathrm{n}}$. Generally, factors causing $P_{\mathrm{n}}$ decrease could be stomatal or no stomatal. Stomatal regulation is one of the earliest responses to water deficit to prevent water loss albeit at the expense of $\mathrm{CO}_{2}$ diffusion which indirectly encourages photorespiration which reverses photosynthetic assimilation and may damage thylakoid membranes (Pinheiro and Chaves 2010; Samarah et al. 2009). Therefore, the analysis of chlorophyll fluorescence provides an accurate characterization of the plant's response to water deficit (Percival and Sheriffs 2002). 
The two studied Eucalyptus species showed an increase in $F_{0}$ and a decrease in $F_{\mathrm{m}}$ and $F_{\mathrm{v}} / F_{\mathrm{m}}$ as $\Psi_{\mathrm{pd}}$ fell. These trends appeared earlier (at higher $\Psi_{\mathrm{pd}}$ values) in E. torquata. than in E. camaldulensis. When a tree is subjected to severe water deficit, no-stomatal factors are responsible for the decrease in photosynthetic activity and a light-dependent inactivation of PSII photochemistry can occur. This was observed in Eucalyptus (Lawlor and Cornic 2002; Lima et al. 2003). Similar results were reported in several perennial plants including Eucalyptus (Lima et al. 2003), Casuarina equisetifolia (Sánchez-Rodriguez et al. 1997), Quercus pubescens (Gallé et al. 2007) and olive (Ennajeh et al. 2009). In this study, the highest $F_{0}$ was recorded in E. torquata which indicates greater destruction of PSII reaction centers due to dehydration compared to E. camaldulensis. Furthermore, values of $F_{\mathrm{v}} / F_{\mathrm{m}}$ below 0.8 are usually interpreted as an indication of photoinhibitory stress (Maxwell and Johnson 2000). In our study, photo-inhibition was more pronounced and occurred earlier in E. torquata than in E. camaldulensis.

\section{Variability in vulnerability to xylem embolism}

Efficient hydraulics of the xylem sustain and improve water transport in the whole plant, thus allowing to maintain plant turgor, growth and to improve survival. Photosynthetic capacity is highly correlated with the hydraulic supply of water to the leaves. Therefore, drought-induced xylem embolism can affect photosynthesis (Martorell et al. 2013). Hydraulic failure was found to be the primary mechanism of leaf and branch dieback in Eucalyptus piperita in response to natural drought events in the field ( $\mathrm{Li}$ et al. 2018). Our results show that both Eucalyptus species understudy were noticeably resistant to xylem embolism having $\Psi_{50}$ values more negative than - 4.5 MPa. Nevertheless, E. camaldulensis was less vulnerable to xylem embolism than $E$. torquata since it had a $\Psi_{50}$ of $-5.4 \mathrm{MPa}$; this value is lower than what was previously reported for the same species $(-4.3 \mathrm{MPa})$ (Nolf et al. 2017). The disparity could be due to different clones or ecotypes may have been used in the two studies. Generally, the response to drought-induced xylem embolism depends on various defense mechanisms. It may be influenced by anatomical traits of the wood as well as by several physiological mechanisms like stomatal closure and the accumulation of osmotic metabolites (Brodersen and McElrone 2013; Jacobsen et al. 2018). Several plant species increase the retention of water in their tissues and their capacity to extract soil moisture by actively increasing the concentration of their xylem sap (Ewers et al. 2001; Hacke and Sperry 2003).

\section{Stomatal functioning correlated with photosynthesis but not with xylem cavitation}

In the present study, $g_{\mathrm{s}}$ appears well correlated with $P_{\mathrm{n}}$. In fact, $g_{\mathrm{s}}$ was high in E. camaldulensis when $P_{\mathrm{n}}$ was also high but it was weak in E. torquata allowing to low $P_{\mathrm{n}}$ specifically when water deficit was intensified. High stomatal conductance in E. camaldulensis leaves may be related to high cell turgor made possible by enhanced osmoregulation as indicated by low $\Psi_{\mathrm{s}}$. Early closure of stomata is an efficient mechanism to prevent xylem embolism induction (Ennajeh et al. 2008; Sevanto 2018). In the present study, despite the early closure of its stomata, E. torquata was more vulnerable to xylem embolism than $E$. camaldulensis. Early stomatal closure does not completely eliminate supplementary embolism (Brodribb et al. 2016; Hochberg et al. 2017). It was demonstrated in several species that water potential thresholds for stomata closure are not correlated to embolism induction (Martin-StPaul et al. 2017). E. camaldulensis plants maintained their stomata open even at fairly low water potentials. Therefore, the resistance of $E$. camaldulensis to xylem cavitation was not related to stomatal behavior but to other defense mechanisms.

\section{Involvement of carbohydrates and cyclitols in Eucalyptus survival}

To alleviate the negative consequences of water deprivation, Eucalyptus plants have developed biochemical responses by accumulating compatible organic compounds (Pita and Pardos 2001; Guarnaschelli et al. 2003; Cha-um and Kirdmanee 2010). Carbohydrates dominate leaf metabolite profile of Eucalyptus from dry areas (Warren et al. 2011). These have an important role in osmoregulation to maintain cell turgor, and in osmoprotection of vital cell constituents (Chaves et al. 2003; Vendruscolo et al. 2007; Anjum et al. 2011; Chen et al. 2011). The present study shows that moderate scarcity of water enhanced the accumulation of total soluble sugars in the leaves of E. camaldulensis and E. torquata. Our findings were consistent with the results reported by Shvaleva et al. (2006) which show a large accumulation of soluble sugars in the leaves of Eucalyptus globulus clones under water stress conditions. However, under severe water stress, E. camaldulensis and E. torquata behaved differently. The former continued to accumulate soluble sugars, whereas the latter reduced sharply the concentration of sugars in its leaves. It seems that soluble sugars were involved in osmoregulation and osmoprotection in E. camaldulensis, but only in osmoregulation in E. torquata. The inter-specific variability in the response to drought in Eucalyptus was highly correlated to differences in carbohydrates metabolism (Warren et al. 2011). Our results show that glucose and fructose were the main soluble sugars accumulated by 
E. camaldulensis under drought stress, but they were much less abundant in E. torquata. In addition, cyclitols are key compatible solutes accumulated in plants in response to drought (Arndt et al. 2004; Merchant et al. 2006). Myoinositol may act as a precursor for a number of secondary messengers (Al-Suod et al. 2017). For instance, quercitol is highly accumulated in water-stressed Eucalyptus trees where it contributes to osmotic adjustment (Merchant et al. 2010). Our study revealed some disparities between the two studied species regarding the concentration of cyclitols in their leaves. In fact, as water stress intensified, E. camaldulensis accumulated myo-inositol, pinitol and quercitol, whereas $E$. torquata held the concentrations of these compounds steady. This may partially explain the fitness of E. camaldulensis. Merchant et al. (2010) demonstrated that quercitol accumulated differently in Eucalyptus species; it was abundant in some but not in others. Eucalyptus species from xeric ecosystems accumulate more quercitol than those from mesic ecosystems when they are exposed to drought (Merchant et al. 2006).

\section{Recovery after severe dehydration}

In woody species, the ability of recover after episodes of water shortage is equally important as the ability to withstand the stress itself. After re-watering, the two studied species regained their pre-stress water status $\left(\Psi_{\mathrm{pd}}\right.$ and $\left.\Psi_{\mathrm{p}}\right)$ with slight advantage for E. camaldulensis. A complete recovery of $\Psi_{\text {pd }}$ was also observed in other Eucalyptus species following drought spells (Warren et al. 2011, 2012). However, it is worth noticing that despite regaining its pre-stress water potentials, E. torquata did not fully restore its $P_{\mathrm{n}}$ even after 30 days of re-watering; whereas, E. camaldulensis displayed $P_{\mathrm{n}}$ rates comparable to those measured prior to imposing water deficit. These results concord with those reported in E. argophloia and in Eucalyptuses clones (E. grandis $\times$ E. nurophylla) plants which recovered their gas exchange activity after interrupting the dry phase (Ngugi et al. 2004; Eksteen et al. 2013). The difference in the ability of E. camaldulensis and E. torquata to restore photosynthetic activity after a drought period was not stomata dependent, because both species regained totally their pre-stress stomatal conductance. In addition, both accomplished a complete restoration of all measured fluorescence variables after 30 days of re-watering meaning that the structural and functional integrity of thylakoid membranes and chlorophyll antenna of the leaves were fully restored. Thus, the difference in photosynthesis resilience between the two species may be related to differences in the ability to maintain and recover mesophyll cell turgor. E. camaldulensis was more effective in maintaining positive cell turgor than E. torquata. Furthermore, because recovery of photosynthetic capacity after drought dependents on the plant's ability to restore xylem function (Martorell et al. 2013), the first species restored more effectively its water status and leaf turgidity. After resuming irrigation, E. camaldulensis quickly regained its pre-stress xylem conductivity level, whereas $E$. torquata accomplished only partial recovery. In E. pauciflora, stem hydraulic conductance was recovered to control levels within 6 days after re-watering following severe water deficit suggesting an active mechanism of embolism repair (Martorell et al. 2013). However, in E. piperita, post-drought embolism refilling was minimal or absent ( $\mathrm{Li}$ et al. 2018). It is evident that in the Eucalyptus genus, there is an inter-specific variability in the plant's capacity to recover its xylem function after drought-induced embolism. The refilling of embolized xylem conduits can be realized by osmotic attractive force on water molecules; this is possible through the secretion of soluble solutes by the living parenchyma cells into the xylem conduits (Bucci et al. 2003; Nardini et al. 2011; Perrone et al. 2012). These solutes include inorganic ions and organic molecules, such as sugars (Tyree et al. 1999; Ameglio et al. 2004; Salleo et al. 2004). Refilling of embolized xylem is most certainly an active mechanism with high nutritive and energy cost.

Mediterranean arid climate (as is the case in southern Tunisia) is characterized by severe and long drought episodes followed by torrential rain. Afforestation projects in such habitat must take into consideration this climate specificity. To colonize such ecosystems, Eucalyptus species have to possess an integrative suitable response to drought which enables a rapid and efficient recovery when water becomes available. The response may include physiological, biochemical and hydraulic mechanisms. In the present study, the biochemical behavior during dehydration-rehydration phases appears to be more suitable in E. camaldulensis. In fact, when moisture was deficient, this species spent more energy accumulating osmotically actives compounds to withstand water stress. When favorable water conditions were restored, it reduced osmotica content in its leaves to save energy and carbon for growth and development. In addition, its ability to quickly restore full xylem conductivity is a critical survival character.

\section{Conclusions}

A significant difference between $E$. camaldulensis and $E$. torquata concerning their response to drought stress was established. E. camaldulensis demonstrated a better capacity to maintain its water status, photosynthetic activity and xylem conductance during drought than $E$. torquata. It was more resilient during the desiccation period and more capable of recovering after returning to favourable moisture conditions than E. torquata. The fitness of E. camaldulensis may be related, at least partially, to its significant resilience 
to xylem embolism and its capacity to osmotically adjust to the drying soil by accumulating sugars and cyclitolsin its leaves during moderate and severe dehydration. These compatible solutes may be involved in osmoregulation as well as in osmoprotection of macromolecules and membranes. They may also contribute to in the resistance to xylem embolism and facilitate the refilling of embolized xylem vessels upon restoring irrigation. It appears that variability in the resilience to xylem embolism and the capacity to accumulate sugars and cyclitols between the two studied Eucalyptuses may be key factors responsible for their distinctive response to drought. Therefore, resilience to xylem embolism and osmotic adjustment by accumulating cyclitols may be reliable criteria for the selection of drought-resilient Eucalyptus genotypes. These findings will need to be confirmed by generalizing the study to other Eucalyptus species using field-grown trees. Furthermore, as both studied Eucalyptus species are not native to the area, other factors such as the potential of becoming invasive, competition with native flora, consumption of soil nutrient and ground water reserves and inflammability should be given due consideration before proceeding to large scale planting.

Author contribution statement ME, SS and NM conceived and designed experiments. SS and ME performed experiments and analyzed data. The manuscript was written by SS and ME and revised by HK and HC. All authors have given consent to the publication of the final version of the manuscript.

\section{Compliance with ethical standards}

Conflict of interest The authors declare that they have no conflict of interest.

\section{References}

Albouchi A, Sebei H, Mezni M, El Aouni M (2000) Influence de la durée d'une alimentation hydrique déficiente sur la production de biomasse, la surface transpirante et la densité stomatique d'Acacia cyanophylla Lindl. Annales de l'INGRE 4:139-161

Allen CD, Macalady AK, Chenchouni H, Bachelet D, McDowell N, Vennetier M, Kitzberger T, Rigling A, Breshears DD, Hogg ET (2010) A global overview of drought and heat-induced tree mortality reveals emerging climate change risks for forests. For Ecol Manag 259:660-684

Al-Suod H, Ligor M, RatSiu IA, Rafinsk K, Góreckid R, Buszewski B (2017) A window on cyclitols: characterization and analytics of inositols. Phytochem Lett 20:507-519

Ameglio T, Decourteix M, Alves G, Valentin V, Sakr S, Julien JL, Petel G, Guilliot A, Lacointe A (2004) Temperature effects on xylem sap osmolarity in walnut trees: evidence for a vitalistic model of winter embolism repair. Tree Physiol 24:785-793

Anjum SA, Xie X-Y, Wang L-C, Saleem MF, Man C, Lei W (2011) Morphological, physiological and biochemical responses of plants to drought stress. Afr J Agric Res 6:2026-2032

Aranda I, Castro L, Pardos M, Gil L, Pardos J (2005) Effects of the interaction between drought and shade on water relations, gas exchange and morphological traits in cork oak (Quercus suber L) seedlings. Forest Ecol Manag 210:117-129

Arndt A, Westblad P, Winson I, Hashimoto T, Lundberg A (2004) Ankle and subtalar kinematics measured with intracortical pins during the stance phase of walking. Foot Ankle Int 25:357-364

Arnould P, Hotyat M (2003) Eau et environnement: Tunisie et milieux méditerranéens. ENS éditions

Bachelard E (1985) Effects of soil moisture stress on the growth of seedlings of three eucalypt species 1 seed germination. Aust For Res 15:103 14

Ben Haj Jilani I, Schweitzer P, Khouja ML, Zouaghi M, Gharbi Z (2008) Physicochemical properties and pollen spectra of honeys produced in Tunisia (southwest of Kef). Apiacta 43:38-48

Blum A (2017) Osmotic adjustment is a prime drought stress adaptive engine in support of plant production. Plant Cell Environ 40:4-10

Bohnert HJ, Nelson DE, Jensena RG (1995) Adaptations to environmental stresses. Plant Cell 7:1099-1111

Bousnina R, Mannai SBM, Hamdi AM (2008) Etude d'un projet de reboisement dans la première série forestière de Tabarka. Mémoire de fin d'études. Forêt, Institut Sylvo-Pastoral de Tabarka, Tunisie, p 45

Bréda N, Huc R, Granier A, Dreyer E (2006) Temperate forest trees and stands under severe drought: a review of ecophysiological responses, adaptation processes and long-term consequences. Ann For Sci 63:625-644

Brodersen CR, McElrone AJ (2013) Maintenance of xylem network transport capacity: a review of embolism repair in vascular plants. Front Plant Sci 4:108

Brodribb TJ, Skelton RP, McAdam SAM, Bienaimé D, Lucani CJ, Marmottant P (2016) Visual quantification of embolism reveals leaf vulnerability to hydraulic failure. New Phytol 209:1403-1409

Bucci SJ, Scholz FG, Goldstein G, Meinzer FC, Sternberg LDSL (2003) Dynamic changes in hydraulic conductivity in petioles of two savanna tree species: factors and mechanisms contributing to the refilling of embolized vessels. Plant Cell Environ 26:1633-1645

Cha-um S, Kirdmanee C (2010) Effects of water stress induced by sodium chloride and mannitol on proline accumulation, photosynthetic abilities and growth characters of eucalyptus (Eucalyptus camaldulensis Dehnh). New For 40:349-360

Chaves M (1991) Effects of water deficits on carbon assimilation. J Exp Bot 42:1-16

Chaves MM, Maroco JP, Pereira JS (2003) Understanding plant responses to drought - from genes to the whole plant. Funct plant biol 30:239-264

Chen W, Feng C, Guo W, Shi D, Yang C (2011) Comparative effects of osmotic-, salt-and alkali stress on growth, photosynthesis, and osmotic adjustment of cotton plants. Photosynthetica 49:417

Chourabi S (2014) Elaboration d'un projet de reboisement: un million d'arbres en collaboration avec la société civile 'Almadanya'. Institut national agronomique de Tunisie, Tunis, $\mathrm{p} 98$

Cochard H, Granier A (1999) Fonctionnement hydraulique des arbres forestiers. Revue Forestière Française 50:121-134

Cochard H, Bodet C, Ameglio T, Cruiziat P (2000) Cryo-scanning electron microscopy observations of vessel content during transpiration in walnut petioles: facts or artifacts? Plant Physiol 124:1191-1202

Correia B, Pintó-Marijuan M, Neves L, Brossa R, Dias MC, Costa A, Castro BB, Araújo C, Santos C, Chaves MM (2014) Water 
stress and recovery in the performance of two Eucalyptus globulus clones: physiological and biochemical profiles. Physiol Plant 150:580-592

Demirevska K, Zasheva D, Dimitrov R, Simova-Stoilova L, Stamenova M, Feller U (2009) Drought stress effects on Rubisco in wheat: changes in the Rubisco large subunit. Acta Physiol Plant 31:1129

DGF (2007) Guide technique du reboisement en Tunisie. Ministère de l'Agriculture et des Ressources Hydriques, Tunis, p 286

DGF (2010) Guide pratique de production en hors sol de plants forestiers, pastoraux et ornementaux en Tunisie, Tunis

Dia A, Duponnois R (2010) Le projet majeur africain de la Grande Muraille Verte Concepts et mise en œuvre Marseille, Institut de Recherche pour le Développement, Tunis, p 439

Edenhofer O, Pichs-Madruga R, Sokona Y, Farahani E, Kadner S, Seyboth K, Adler A, Baum I, Brunner S, Eickemeier P (2014) Summary for policymakers. In: Climate change, mitigation of climate change. Contribution of working group III to the fifth assessment report of the Intergovernmental Panel on Climate Change

Eksteen AB, Grzeskowiak V, Jones NB, Pammenter NW (2013) Stomatal characteristics of Eucalyptus grandis clonal hybrids in response to water stress Southern Forests. J For Sci 75:105-111

El Atta HA, Aref IM, Ahmed AI, Khan PR (2012) Morphological and anatomical response of Acacia ehrenbergiana Hayne and Acacia tortilis (Forssk) Haynes subspp raddiana seedlings to induced water stress. Afr J Biotechnol 11:10188-10199

El-Euch F (2011) Atelier régional forets, parcours et changement climatique dans la région du moyen orient Rapport national

Ennajeh M, Vadel AM, Khemira H, Ben Mimoun M, Hellali R (2006) Defense mechanisms against water deficit in two olive (Olea europaea L.) cultivars 'Meski' and 'Chemlali'. J Hortic Sci Biotechnol 81:99-104

Ennajeh M, Tounekti T, Vadel AM, Khemira H, Cochard H (2008) Water relations and drought-induced embolism in olive (Olea europaea) varieties 'Meski' and 'Chemlali' during severe drought. Tree physiol 28:971-976

Ennajeh M, Vadel AM, Khemira H (2009) Osmoregulation and osmoprotection in the leaf cells of two olive cultivars subjected to severe water deficit. Acta Physiol Plant 31:711-721

Ewers FW, Ameglio T, Cochard H, Beaujard FO, Martignac M, Vandame $M$ et al (2001) Seasonal variation in xylem pressure of walnut trees: root and stem pressures. Tree Physiol 21:1123-1132

Gallé A, Haldimann P, Feller U (2007) Photosynthetic performance and water relations in young pubescent oak (Quercus pubescens) trees during drought stress and recovery. New Phytol 174:799-810

Genty B, Briantais JM, Baker NR (1989) The relationship between the quantum yield of photosynthetic electron transport and quenching of chlorophyll fluorescence. Biochim et Biophys Acta Gen Subj 990:87-92

Guarnaschelli AB, Lemcoff JH, Prystupa P, Basci SO (2003) Responses to drought preconditioning in Eucalyptus globulus Labill provenances. Trees 17:501-509

Hacke UG, Sperry JS (2003) Limits to xylem refilling under negative pressure in Laurus nobilis and Acer negundo. Plant Cell Environ 26:303-311

Hochberg U, Windt CW, Ponomarenko A, Zhang Y, Rockwell FE, Holbrook NM (2017) Stomatal closure, basal leaf embolism and shedding protect the hydraulic integrity of grape stems. Plant Physiol 174:764-775

Hoerling M, Eischeid J, Perlwitz J, Quan X, Zhang T, Pegion P (2012) On the increased frequency of Mediterranean drought. J Clim 25:2146-2161

Hu H, Chen H, Hu T, Zhang J (2012) Adaptability comparison between the seedlings of Eucalyptus grandis and Alnus cremastogyne under the condition of continuous drought stress. J Agric Sci 4:75-86

SAS Institute (1999) SAS/STAT User's Guide. SAS Institute, Cary
Jacobsen AL, Valdovinos-Ayala J, Pratt RB (2018) Functional lifespans of xylem vessels: development, hydraulic function, and postfunction of vessels in several species of woody plants. Am J Bot 105:142-150

Khouja ML (1999) Amélioration génétique: inventaire et bilan des recherché enterprises en Tunisie Communication présenté au séminaire organize par l'INGREF et la DGF sur la recherché pour le développement forestier tenu à Hammamet-Tunisie du 24 au 25 novembre 1999, 35p

Khouja ML, Khaldi A, Rejeb MN (2001) Resultants of the Eucalyptus introduction trialis in Tunisia Procedings of international conference on Eucalyptus in the Mediterranean Basin: Prospective and new utilization Ed, Centro Propozione Pubblicita, Taormina, Italy, pp163-168

Lamhamedi MS, Ammari Y, Fecteau B, Fortin JA, Margolis H (2000) Problématique des pépinières forestières en Afrique du Nord et stratégies de développement. Cahiers Agric 9:369-380

Lawlor DW, Cornic G (2002) Photosynthetic carbon assimilation and associated metabolism in relation to water deficits in higher plants. Plant Cell Environ 25:275-294

Lemcoff JH, Guarnaschelli AB, Garau AM, Prystupa P (2002) Elastic and osmotic adjustments in rooted cuttings of several clones of Eucalyptus camaldulensis Dehnh from southeastern Australia after a drought. Flora 197:134-142

Lima WDP, Jarvis P, Rhizopoulou S (2003) Stomatal responses of Eucalyptus species to elevated $\mathrm{CO} 2$ concentration and drought stress. Sci Agric 60:231-238

Li X, Blackman CJ, Rymer PD, Quintans D, Duursma RA, Choat B, Tissue DT (2018) Xylem embolism measured retrospectively is linked to canopy dieback in natural populations of Eucalyptus piperita following drought. Tree Physiol 38:1193-1199

Martin-StPaul N, Delzon S, Cochard H (2017) Plant resistance to drought depends on timely stomatal closure. Ecol Lett 20:1437-1447

Martorell S, Diaz-Espejo A, Medrano H, Ball MC, Chaot B (2013) Rapid hydraulic recovery in Eucalyptus pauciflora after drought: linkages between stem hydraulics and leaf gas exchange. Plant Cell Environ 37:617-626

Maxwell K, Johnson GN (2000) Chlorophyll fluorescence-a practical guide. J Exp Bot 51:659-668

Merchant A, Tausz M, Arndt SK, Adams MA (2006) Cyclitols and carbohydrates in leaves and roots of 13 Eucalyptus species suggest contrasting physiological responses to water deficit. Plant Cell Environ 29:2017-2029

Merchant A, Callister A, Arndt S, Tausz M, Adams M (2007) Contrasting physiological responses of six Eucalyptus species to water deficit. Ann Bot 100:1507-1515

Merchant A, Arndt S, Rowell D, Posch S, Callister A, Tausz M, Adams M (2010) Seasonal changes in carbohydrates, cyclitols, and water relations of 3 field grown Eucalyptus species from contrasting taxonomy on a common site. Ann For Sci 67:104

Moing A, Carbonne F, Rashad MH, Gaudillere JP (1992) Carbon fluxes in mature peach leaves. Plant Physiol 100:1878-1884

Mokotedi ME (2010) Physiological responses of Eucalyptus nitens $\times$ nitens under experimentally imposed water stress. South For 72:63-68

Morales C, Pino M, Del Pozo A (2013) Phenological and physiological responses to drought stress and subsequent rehydration cycles in two raspberry cultivars. Sci Hortic 162:234-241

Morgan JM (1984) Osmoregulation and water stress in higher plants. Annu Rev Plant Physiol 35:299-319

Nardini A, Lo Gullo MA, Salleo S (2011) Refilling embolized xylem conduits: is it a matter of phloem unloading? Plant Sci 180:604-611

Navarrete-Campos D, Bravo LA, Rubilar RA, Emhart V, Sanhueza R (2013) Drought effects on water use efficiency, freezing tolerance 
and survival of Eucalyptus globulus and Eucalyptus globulus $\times$ nitens cuttings. New For 44:119-134

Ngugi MR, Doley D, Hunt MA, Ryan P, Dart P (2004) Physiological responses to water stress in Eucalyptus cloeziana and $E$ argophloia seedlings. Trees 18:381-389

Nobel P (1991) Physicochemical and environmental plant physiology. Academic Press, San Diego

Nolf M, Lopez R, Peters JMR, Flavel RJ, Koloadin LS, Young IM, Choat B (2017) Visualization of xylem embolism by X-ray microtomography: a direct test against hydraulic measurements. New Phtytol 214:890-898

Orthen B, Popp M (2000) Cyclitols as cryoprotectants for spinach and chickpea thylakoids. Environ Exp Bot 44:125-132

Peltzer D, Dreyer E, Polle A (2002) Differential temperature dependencies of antioxidative enzymes in two contrasting species: Fagus sylvatica and Coleus blumei. Plant Physiol Biochem 40:141-150

Percival GC, Sheriffs CN (2002) Identification of drought-tolerance woody perennials using chlorophyll fluorescence. Arboric J 28:215-223

Perrone I, Pagliarani C, Lovisolo C, Chitarra W, Roman F, Schubert A (2012) Recovery from water stress affects grape leaf petiole transcriptome. Planta 235:1383-1396

Pinheiro C, Chaves M (2010) Photosynthesis and drought: can we make metabolic connections from available data? J Exp Bot 62:869-882

Pita P, Pardos JA (2001) Growth, leaf morphology, water use and tissue water relations of Eucalyptus globulus clones in response to water deficit. Tree Physiol 21:599-607

Popp M, Lied W, Bierbaum U, Gross M, Grosse-Schulte T, Hams S, Oldenettel J, Schuler S, Wiese J (1997) Cyclitols—stable osmotica in trees. In: Rennenberg H, Eschrich W, Ziegler H (eds) Treescontributions to modern tree physiology. Backhuys Publishers, Leiden, pp 257-270

Poupon H (1968) Premieres études des caracteristiques hydriques des feuilles d'Eucalyptus camaldulensis en Tunisie. Annales de l'Institut National de Recherches Forestières de Tunisie $1(03): 1-22$

Robyt J, White B (1987) Biochemical techniques-theory and practice. Cole Publishing Company, Monterey, pp 267-275

Salleo S, Lo Gullo MA, Trifilo P, Nardini A (2004) New evidence for a role of vessel-associated cells and phloem in the rapid xylem refilling of cavitated stems of Laurus nobilis L. Plant Cell Environ 27:1065-1076

Samarah N, Alqudah A, Amayreh J, McAndrews G (2009) The effect of late-terminal drought stress on yield components of four barley cultivars. J Agron Crop Sci 195:427-441

Sánchez-Rodriguez J, Martinez-Carrasco R, Pérez P (1997) Photosynthetic electron transport and carbon-reduction-cycle enzyme activities under long-term drought stress in Casuarina equisetifolia. Forst Forst Photosynth Res 52:255-262

Sapeta H, Costa JM, Lourenco T, Maroco J, Van der Linde P, Oliveira MM (2013) Drought stress response in Jatropha curcas: growth and physiology. Environ Exp Bot 85:76-84

Schobert B (1977) Is there an osmotic regulatory mechanism in algae and higher plants? J Theor Biol 68:17-26

Scholander PF, Bradstreet ED, Hemmingsen E, Hammel H (1965) Sap pressure in vascular plants: negative hydrostatic pressure can be measured in plants. Science 148:339-346
Sevanto S (2018) Drought impacts on phloem transport. Curr Opin Plant Biol 43:76-81

Shvaleva AL, Silva FCE, Breia E, Jouve J, Hausman JF, Almeida MH, Maroco J, Rodrigues M, Pereira JS, Chaves MM (2006) Metabolic responses to water deficit in two Eucalyptus globulus clones with contrasting drought sensitivity. Tree Physiol 26:239-248

Smirnoff N (1993) The role of active oxygen in the response of plants to water deficit and desiccation. New Phytol 125:27-58

Sperry J, Donnelly J, Tyree M (1988) A method for measuring hydraulic conductivity and embolism in xylem. Plant Cell Environ $11: 35-40$

Stape JL, Binkley D, Ryan MG (2004) Eucalyptus production and the supply, use and efficiency of use of water, light and nitrogen across a geographic gradient in Brazil. For Ecol Manag 193:17-31

Tognetti R, Longobucco A, Miglietta F, Raschi A (1999) Water relations, stomatal response and transpiration of Quercus pubescens trees during summer in a Mediterranean carbon dioxide spring. Tree Physiol 19:261-270

Toscano S, Ferrante A, Romano D (2019) Response of Mediterranean ornamental plants to drought stress. Horticulturae 5:6

Tyree MT, Zimmermann MH (2002) Xylem structure and the ascent of sap. Springer, New York

Tyree MT, Salleo S, Nardini A, Lo Gullo MA, Mosca R (1999) Refilling of embolized vessels in young stems of laurel: do we need a new paradigm? Plant Physiol 120:11-21

Vendruscolo ECG, Schuster I, Pileggi M, Scapim CA, Molinari HBC, Marur CJ, Vieira LGE (2007) Stress-induced synthesis of proline confers tolerance to water deficit in transgenic wheat. J Plant Physiol 164:1367-1376

Villar E, Klopp C, Noirot C, Novaes E, Kirst M, Plomion C, Gion JM (2011) RNA-Seq reveals genotype-specific molecular responses to water deficit in Eucalyptus. BMC Genom 12:538

Warren CR, Aranda I, Cano FJ (2011) Responses to water stress of gas exchange and metabolites in Eucalyptus and Acacia spp. Plant Cell Environ 34:1609-1629

Warren CR, Aranda I, Cano FJ (2012) Metabolomics demonstrates divergent responses of two Eucalyptus species to water stress. Metabolomics 8:186-200

White DA, Turner NC, Galbraith JH (2000) Leaf water relations and stomatal behavior of four allopatric Eucalyptus species planted in Mediterranean southwestern Australia. Tree Physiol 20:1157-1165

Zaafouri MS (1993) Contraintes du milieu et réponses de quelques espèces arbustives exotiques introduites en Tunisie présaharienne Science et changements planétaires. Sécheresse 4:201-201

Zhu JK (2001) Plant salt tolerance. Trends Plant Sci 6:66-71

Publisher's Note Springer Nature remains neutral with regard to jurisdictional claims in published maps and institutional affiliations. 